\title{
Seasonal patterns in grazing mortality of bacterioplankton in polar oceans: a bipolar comparison
}

\author{
M. Robin Anderson ${ }^{1, *}$, Richard B. Rivkin ${ }^{2}$ \\ ${ }^{1}$ Science Branch, Department of Fisheries and Oceans, PO Box 5667, St. John's, Newfoundland A1C 5X1, Canada \\ ${ }^{2}$ Ocean Sciences Centre, Memorial University of Newfoundland, St. John's, Newfoundland A1C 5S7, Canada
}

\begin{abstract}
Despite the relevance of high latitude oceans to models and budgets of biogenic carbon, and the central role of heterotrophic microbes in global biogeochemical cycles, the patterns of energy flow through the lower food web in polar regions are poorly understood. To assess bacteriabased food webs in polar regions, the distribution, growth, and respiration and grazing losses of bacteria must be characterized. We report on the results of a seasonal (late winter through late summer) study of protist grazing in both Resolute Bay, Northwest Territories, Canadian Arctic and McMurdo Sound, Antarctica, and summarize the literature on the relations between the growth and grazing mortality of polar bacterioplankton. Bacterial abundance varied 5-fold in the Arctic and 25 -fold in the Antarctic. Average bacterial growth rates ranged from 0.1 to $1.1 \mathrm{~d}^{-1}$. During comparable seasons, bacterial abundance was 2- to 3-fold higher and growth rates were 2- to 3-fold lower in the Antarctic than the Arctic. When grazing occurred, microzooplankton consumed nearly all of the local bacterial production. Grazing losses of bacteria were negligible immediately before and after the phytoplankton bloom. We propose that at these times, bacterioplankton were nutrient limited and protists were predominantly herbivorous. Protozoan grazers appear to alternate between bacterivorous and herbivorous nutritional modes as prey fields change in response to the seasonal progression in submarine irradiance and concentration of dissolved nutrients. The timing and magnitude of the phytoplankton bloom and the duration of the post-bloom period exert a significant influence on the flux of bacterioplankton carbon through microzooplankton and ultimately the coupling of the microbial and metazoan food webs.
\end{abstract}

KEY WORDS: Arctic - Antarctic - Bacterioplankton - Grazing mortality - Microbial food web · Microzooplankton $\cdot$ Polar oceans $\cdot$ Protozoa $\cdot$ Nutrient limitation

Resale or republication not permitted without written consent of the publisher

\section{INTRODUCTION}

The structure of the microbial food web influences the efficiency and magnitude of the transfer of carbon from dissolved pools to metazoan food webs and the deep sea (Ducklow 1991, Fortier et al. 1994, Legendre \& Rassoulzadegan 1995). Heterotrophic flagellates are the principle consumers of bacteria (Sherr \& Sherr 1991, 1994; however, see Bernard \& Rassoulzadegan 1990) and are a major trophic link between picoheterotrophs (and autotrophs) and larger protozoan and metazoan consumers. Flagellates and other protis-

*E-mail: andersonro@dfo-mpo.gc.ca tan grazers significantly influence nutrient fluxes in the low to middle latitude oceans (reviewed by Azam et al. 1994, Caron 1994, Sherr \& Sherr 1994, Thingstadt \& Rassoulzadegan 1995). The magnitude of this influence depends on a number of factors, including protistan abundance, the abundance and size of their prey, the percentage of the total prey biomass grazed by protists relative to that consumed by other organisms (Caron et al. 1985, Bernard \& Rassoulzadegan 1990, Sherr \& Sherr 1994), seawater temperature (Rassoulzadegan 1982, Verity 1985, Andersen et al. 1986, Choi \& Peters 1992), and the efficiency of incorporation of prey into protistan biomass (Rassoulzadegan 1982, Caron et al. 1985, Verity 1985, Choi \& Peters 1992). 
The role of these heterotrophic microbes in mediating nutrient fluxes in high latitude or cold oceans is uncertain (Pomeroy \& Wiebe 1993, Becquevort 1997, Sherr et al. 1997). However, microzooplankton assemblages from polar regions are both diverse and abundant (Buck \& Garrison 1983, Taniguchi 1984, Andersen 1988, Paranjape 1988, Garrison et al. 1991, Nöthig et al. 1991, Garrison \& Gowing 1993). Although information on microbial rate processes is relatively scarce for these regions, based on the distribution of microzooplankton, and extrapolating rate processes from low to high latitudes, it is clear that microbial grazers potentially consume and recycle most local bacterial production (Andersen 1988, Anderson et al. 1990, Moisan et al. 1991, Putt et al. 1991, Laurion et al. 1995).

High latitude oceans account for about 10 to $20 \%$ of oceanic carbon production (Longhurst et al. 1995, Behrenfeld \& Falkowski 1997) and the patterns of energy flow through the lower food web in polar oceans are important to the understanding of global carbon budgets (Azam et al. 1991, Legendre \& Le Fevre 1995, Rivkin \& Anderson 2000). Several recent studies reported high rates of bacterial growth in polar waters (Rivkin et al. 1996, Rich et al. 1997, Carlson et al. 1998, Ducklow 1999, Kelly et al. 1999). Indeed, Rivkin et al. (1996) reported that the growth rates of bacterioplankton from high and low latitude oceans are, on average, not significantly different. In this paper, we report on the results of a seasonal (late winter through late summer) study of microzooplankton grazing in Resolute Bay, Northwest Territories, Canada and McMurdo Sound, Antarctica, and we summarize the published information on the seasonal relations between rates of bacterial growth and grazing losses in polar regions. We found that when grazing occurred, microzooplankton consumed ca $90 \%$ of local bacterial production. Grazing losses of bacteria were insignificant immediately before and after the phytoplankton bloom. At these times, bacterioplankton appeared to be nutrient-limited and protists were predominantly herbivorous. We propose that feedback between phagotrophic protists and their prey is mediated through the control on nutrient availability. This maintains close homeostatic control of prey biomass, thereby minimizing seasonal oscillations in bacterioplankton abundances, optimizing ingestion of high nutritional quality prey.

\section{MATERIALS AND METHODS}

Field sites. In the Canadian Arctic, samples for determination of biomass and rates of bacterial growth and microzooplankton grazing were collected in Resolute Passage $\left(74^{\circ} 38.5^{\prime} \mathrm{N}, 94^{\circ} 51.5^{\prime} \mathrm{W}\right)$ from a depth of
5 to $10 \mathrm{~m}$. An acid-cleaned, 101 Niskin bottle (General Oceanics, Miami, FL)was deployed through a permanent sample hole in the sea ice (March through June and November through December 1993) or from a 'Murphy' boat during the open water period (August through October 1993). The water depth at this site was ca $100 \mathrm{~m}$. Water samples were transferred into acid-cleaned insulated coolers and returned, within $1 \mathrm{~h}$ of collection, to the Resolute Bay Marine Laboratory for subsequent analysis and processing. In McMurdo Sound, samples were collected from 15 to $20 \mathrm{~m}$ by deploying a Niskin bottle through a permanent sample hole in the sea ice at seasonal sea ice camps (Anderson et al. 1990, Rivkin 1991). Samples either were immediately processed at our field laboratory (September through mid-November 1989) or transferred into insulated coolers and returned, within $1 \mathrm{~h}$ of collection, to the Eckland Biological Laboratory for subsequent analysis and processing (late November 1989 through mid-January 1990).

Biomass and bacterial growth rates. The particulate material from replicate 0.5 to 21 water samples was collected onto $25 \mathrm{~mm}$ diameter Whatman GF/F filters and frozen at $-20^{\circ} \mathrm{C}$ until chlorophyll a was extracted in $90 \%$ acetone and determined fluorometrically. Bacterioplankton samples preserved with glutaraldehyde (1.5\% final concentration) were kept cold until slides were prepared, usually within 2 wk of sample collection. Bacteria were filtered onto black $0.2 \mu \mathrm{m}$ Poretics filters (Osmonics, Minnetonka, MN), stained with acridine orange and counted by epifluorescence microscopy (Hobbie et al. 1977).

Bacterial growth rates were computed from the incorporation of [methyl- ${ }^{3} \mathrm{H}$ ] thymidine $\left({ }^{3} \mathrm{H}-\mathrm{TdR}_{i} \mathrm{ICN}\right.$, 60 to $90 \mathrm{Ci} \mathrm{mmol}^{-1}$; final concentration of $5 \mathrm{nmol}$ ). Samples were incubated in replicate $120 \mathrm{ml}$ polycarbonate incubation bottles at $-1.5 \pm 0.2^{\circ} \mathrm{C}$. Triplicate $15 \mathrm{ml}$ aliquots were removed immediately after addition of the isotope $\left(t_{0}\right)$ and at the end of a 3 to $4 \mathrm{~h}$ incubation. The uptake of TdR was saturated at $5 \mathrm{nmol}$ and uptake was linear for 24 to $28 \mathrm{~h}$ at ambient temperatures. Particulate material was collected onto $0.2 \mu \mathrm{m}$ Poretics filters, serially rinsed twice with filtered seawater, 3 times with $3 \mathrm{ml}$ of ice-cold $5 \%$ trichloracetic acid and once with filtered seawater. Filters were placed in liquid scintillation vials and counted as described below. Subsamples to assess the total radioactivity available for uptake were collected from each bottle at both the beginning and the end of the incubation.

Conversion factors relating cell production to substrate uptake were empirically determined (Kirchman et al. 1982) using seawater dilution cultures. Briefly, $<1.0 \mu \mathrm{m}$ filtrate was diluted 1:5 with $0.2 \mu \mathrm{m}$ membrane-filtered seawater. ${ }^{3} \mathrm{H}-\mathrm{TdR}$ was added to 11 polycarbonate incubation bottles containing $900 \mathrm{ml}$ of the 
dilution culture, and the time course of change of cell abundances and the incorporation of TdR were determined at 6 to $12 \mathrm{~h}$ intervals for ca $48 \mathrm{~h}$. All incubations were carried out in the dark at the temperature from the depth of collection $\left(-1.5 \pm 0.2^{\circ} \mathrm{C}\right)$. Conversion factors determined using the integrative (Riemann et al. 1987, Kirchman \& Hoch 1988) and cumulative (Bjørnsen \& Kuparinen 1991) methods were similar.

Radioactivity was counted using a Beckman Model 2800 (Arctic) or Beckman Model 3801 or 6800 (Antarctic) liquid scintillation spectrometer (Beckman Coulter Inc., Fullerton, CA) with Scintiverse (Arctic) (Fisher Scientific, Fairlawn, NJ) or Biofluor (Antarctic) (Packard Bioscience BV, Rigaveg, The Netherlands) as a scintillant. All counts were corrected for quench by the external standards method and for background radiation.

Microzooplankton grazing. In the Arctic, microzooplankton bacterivory was estimated using the dilution assay (Landry \& Hassett 1982, Evans \& Paranjape 1992, Landry 1993, Rivkin et al.1999). Briefly, seawater was gently filtered through a $202 \mu \mathrm{m}$ Nitex mesh (to remove larger grazers) and then diluted with 'particlefree' filtrate prepared by gravity filtration through a $0.2 \mu \mathrm{m}$ Gelman cartridge filter (Pall Gellman Laboratory, Anne Arbor, MI) to the following dilutions: 1:0 (i.e., no dilution), 1:1, 1:3 and 1:7. Samples were incubated in duplicate 41 cubitainers in subdued light (5 to $20 \%$ of incident irradiance) and at or near ambient temperatures $\left(<-1 \mathrm{C}^{\circ}\right.$ in the winter and spring and -1 to $<1^{\circ} \mathrm{C}$ during the bloom and post bloom period). In the Antarctic, grazing of bacterioplankton was estimated for the microzooplankton community in 1:0 and 1:8 dilutions only. Bacterial abundances were determined after a pre-incubation interval of $4 \mathrm{~h}$ (i.e., $t_{0}$ ) and after ca 24 and $48 \mathrm{~h}$. This pre-incubation was incorporated into the experimental design because we occasionally observed large and variable changes in bacterial abundance within the first $2 \mathrm{~h}$ after preparing the dilutions.

Apparent growth rate (AGR) was computed from the time-dependent change in bacterial abundances at the different dilutions. The AGR is the difference between growth $(k)$ and grazing mortality $(g)$. The relation between AGR and dilution factor (DF) did not deviate systematically from linearity; hence, we used a linear rather than an exponential model to estimate $k$ and $g$ (Evans \& Paranjape 1992) and computed $k$ as the ordinal intercept and $g$ as the slope of the regressions of AGR on the observed DF at $t_{0}$. The observed DF was computed from the bacterial abundance at $t_{0}$ in the different dilutions. The observed DF differed from the expected DF by as much as $20 \%$. Hence, by using the observed DF at $t_{0}$ we eliminated a potentially significant source of error in our regression analyses.

\section{RESULTS}

In the Arctic, chlorophyll a concentrations and bacterial abundances and growth rates were measured at 7 to 10 d intervals during March, May, June, August and September and less frequently in April, July, November and December. In the Antarctic, these variables were measured at approximately $10 \mathrm{~d}$ intervals from early September through mid-January. For clarity of presentation, only monthly means are presented. Detailed temporal and spatial patterns in the distribution of microbial biomass and rates of production are described elsewhere (Rivkin 1991, unpubl. data, Rivkin et al. 1994).

\section{Canadian Arctic}

Chlorophyll $a$ in the well-mixed upper water column of the seasonally ice-covered Resolute Passage varied approximately 500-fold between March and December (Fig. 1a). Concentrations ranged from $<10 \mathrm{ng}^{-1}$ under
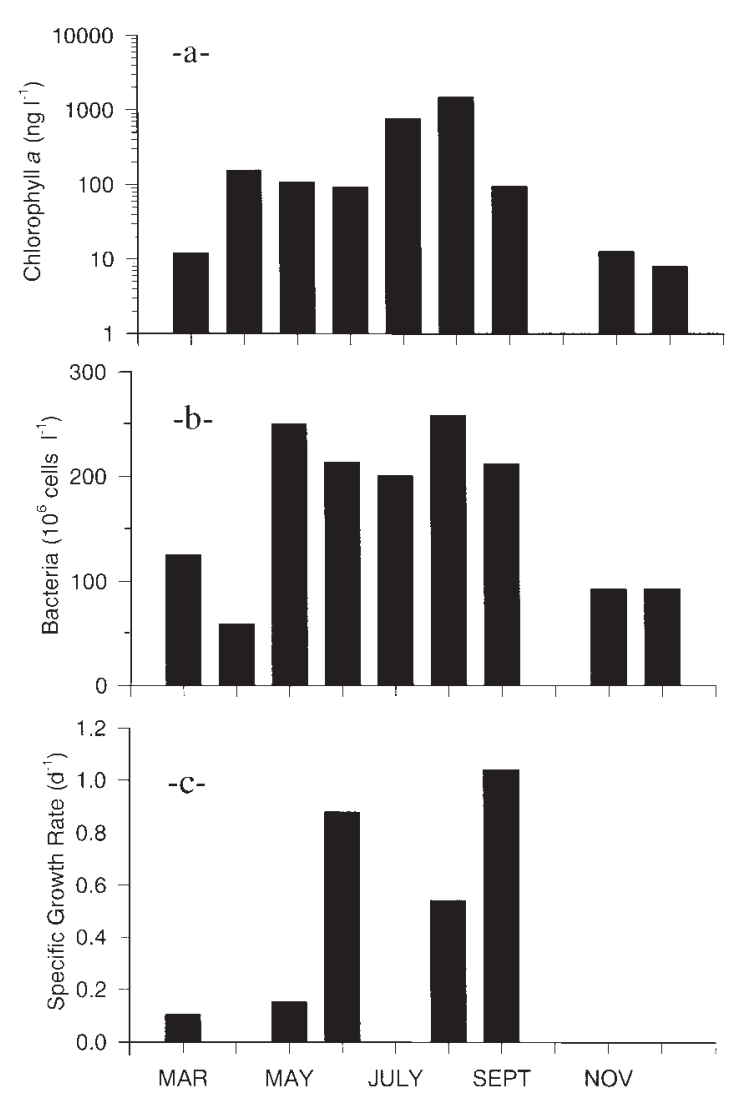

Fig. 1. Representative seasonal patterns of (a) chlorophyll a (ng l $\mathrm{l}^{-1}$ ), (b) bacterial abundance (cells $\mathrm{l}^{-1}$ ) and (c) specific growth rates (SGR) of bacteria from [methyl- ${ }^{3} \mathrm{H}$ ] thymidine $(\mathrm{TdR})$ incubations $\left(\mathrm{d}^{-1}\right)$ at Resolute Bay, Northwest Territories, Canadian Arctic, 1993. Each bar represents 3 to 5 sample periods 
the ice in mid-March to a maximum of approximately $4 \mathrm{\mu g} \mathrm{l}^{-1}$ during early August when the sea ice melted and dispersed. There was a 10 -fold increase between mid-March and late April, from approximately 10 to $100 \mathrm{ng} \mathrm{l}^{-1}$, followed by a small decline to 50 to $70 \mathrm{ng} \mathrm{l}^{-1}$ during May and early June, an increase through July and August and a decline thereafter (Fig. 1a). Bacterioplankton abundances varied approximately 5 -fold, from 60 to $330 \times \quad 10^{6}$ cells l $^{-1}$, between early March and late December (Fig. 1b). There was a 2-fold decrease between mid-March and mid-April, an increase to plateau concentrations of ca 200 to $300 \times \quad 10^{6}$ cells l$^{-1}$ from May through September and a decrease thereafter. The average bacterial growth rate in the upper mixed layer (Fig. 1c) was low in March through May $(<0.2$ $\mathrm{d}^{-1}$ ) and increased during June through September where rates varied between 0.6 and $\sim 1.0 \mathrm{~d}^{-1}$. Throughout this period, water temperatures were -1.8 to $0^{\circ} \mathrm{C}$.
Grazing mortality of bacteria was high (0.15 to $0.88 \mathrm{~d}^{-1}$ ) during the winter, spring and phytoplankton bloom periods. Microzooplankton consumed 90 to $190 \%$ of bacterial production (Table 1) at these times. However, during the pre- and post-bloom periods, grazing mortality declined to undetectable levels.

\section{McMurdo Sound}

During the late austral winter through early austral summer, chlorophyll a concentrations in the upper water column increased by approximately a 1000 -fold, from $<10 \mathrm{ng} \mathrm{l}^{-1}$ during late August through late September to 4 to $6 \mathrm{\mu g} \mathrm{l}^{-1}$ during late December through early January (Fig. 2a and Rivkin 1991). During this same period, the monthly averaged bacterial abundance in the upper $30 \mathrm{~m}$ at our sample site increased approximately 25 -fold, from 60 to 1450

Table 1. Rates of growth and grazing mortality for bacterioplankton from polar regions during different seasons. In all cases, incubation and ambient temperatures were $<-1^{\circ} \mathrm{C}$ in the winter and spring and -1 to $<1^{\circ} \mathrm{C}$ during the bloom and post-bloom period. Unless otherwise indicated, growth and grazing rates are for planktonic microheterotrophs. When more than 1 observation was available for a time period, they are listed as a range. NS: not significantly different from zero; ND: not determined

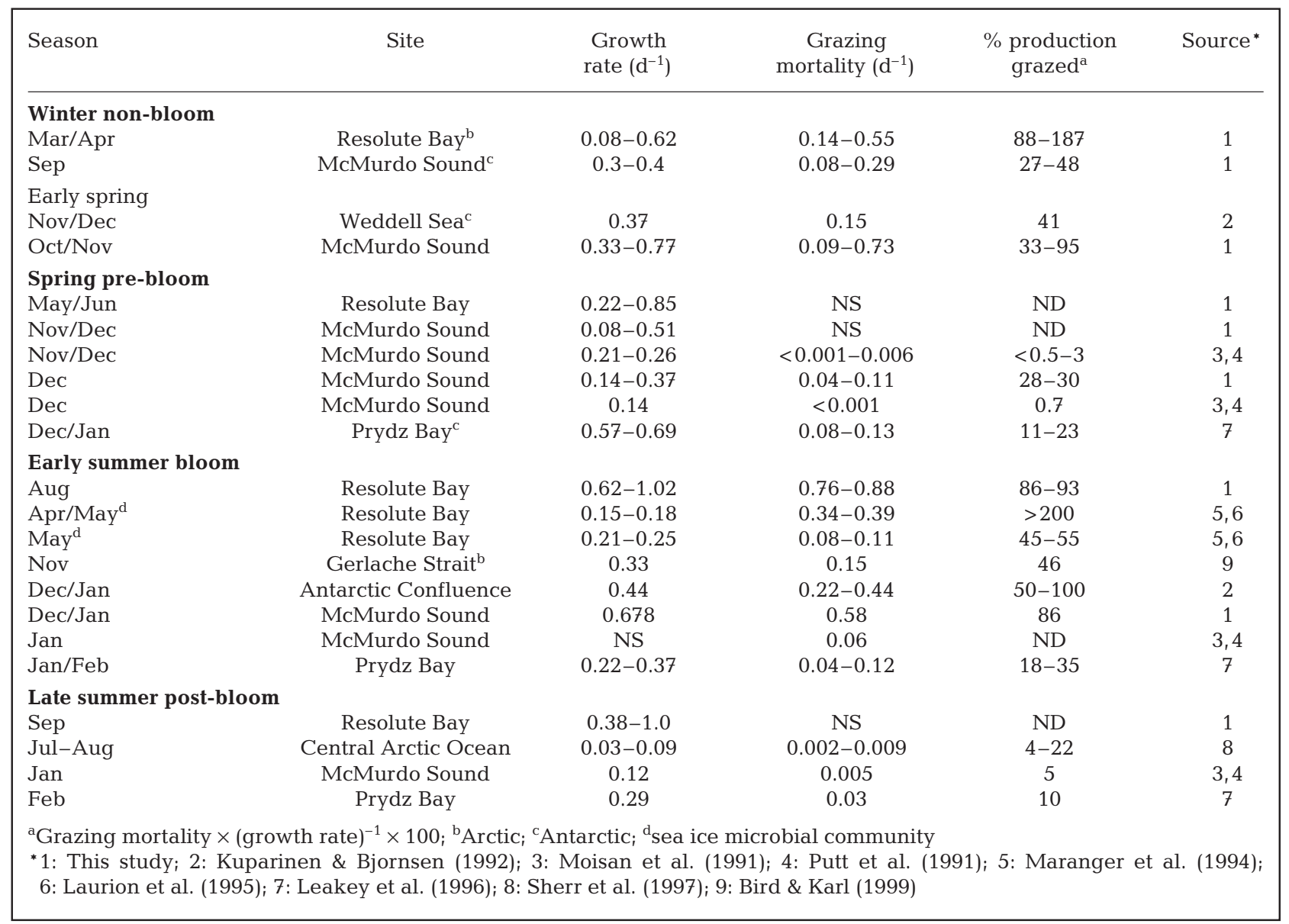


$\times$

$10^{6} \mathrm{l}^{-1}$ (Fig. 2b and Rivkin

1991), and bacterial growth rates (Fig. 2c) were higher in September, October and late December (0.4 to 0.65 $\mathrm{d}^{-1}$ ) than in November, early December and January (0.15 to $\left.0.3 \mathrm{~d}^{-1}\right)$.

Grazing mortality of bacteria varied from ca 0.05 to $0.73 \mathrm{~d}^{-1}$ over the season (Table 1). Rates were highest during the late winter through mid-spring (early September through early November; 0.3 to $0.73 \mathrm{~d}^{-1}$ ), and again when chlorophyll a concentrations in the water column under the sea ice were high (i.e., late December through early January; $0.58 \mathrm{~d}^{-1}$ ). Grazing mortality was lowest $\left(<0.1 \mathrm{~d}^{-1}\right)$ before and after the periods when phytoplankton abundances were high (early to mid-December and mid- to late January). Microzooplankton generally consumed 20 to $90 \%$ of the bacterial production during the late-winter through early spring as well as during the phytoplankton bloom. In contrast, grazing rates were low (0 to $30 \%$ of local bacterial production) immediately before (Table 1) and after the phytoplankton bloom (Moisan et al. 1991, Putt et al. 1991).

\section{DISCUSSION}

Our understanding of the structure and function of the lower food web in marine pelagic ecosystems has evolved over the past 2 decades. We now know that heterotrophic microbial metabolism is an important, and at times dominant, pathway for organic matter transformation in the sea (Azam et al. 1983, Legendre \& Le Fevre 1995, Azam 1998). Although some flagellates can take up dissolved or colloidal organic material (Marchant \& Scott 1993, Tranvik 1994), bacteria are normally the first link in the microbial trophic pathway from DOC to protistan and metazoan grazers. Bacteria and bacterial-based food webs influence sinking fluxes by altering both the size of sinking particles and the equilibrium between the particulate and dissolved phases (Cho \& Azam 1990); thus, they are important in material processing, respiration and carbon remineralization within, and export from, the surface layer of the ocean (Rivkin \& Legendre 2001). It is this export of biogenic carbon that contributes to the net flux of atmospheric $\mathrm{CO}_{2}$ into the ocean's interior. While it is recognized that heterotrophic microbial pathways recycle 20 to $60 \%$ of pelagic primary production in temperate and tropical marine ecosystems (Cole et al. 1988, White et al. 1991, Ducklow 1999, 2000), bacterial-mediated elemental fluxes can be highly variable in both rate and composition (Findlay et al. 1991, Hoch \& Kirchman 1993, Azam et al. 1994, Azam 1998).

Bacteria transform the DOC that is released from phytoplankton either directly (as excretion, viral lysis)
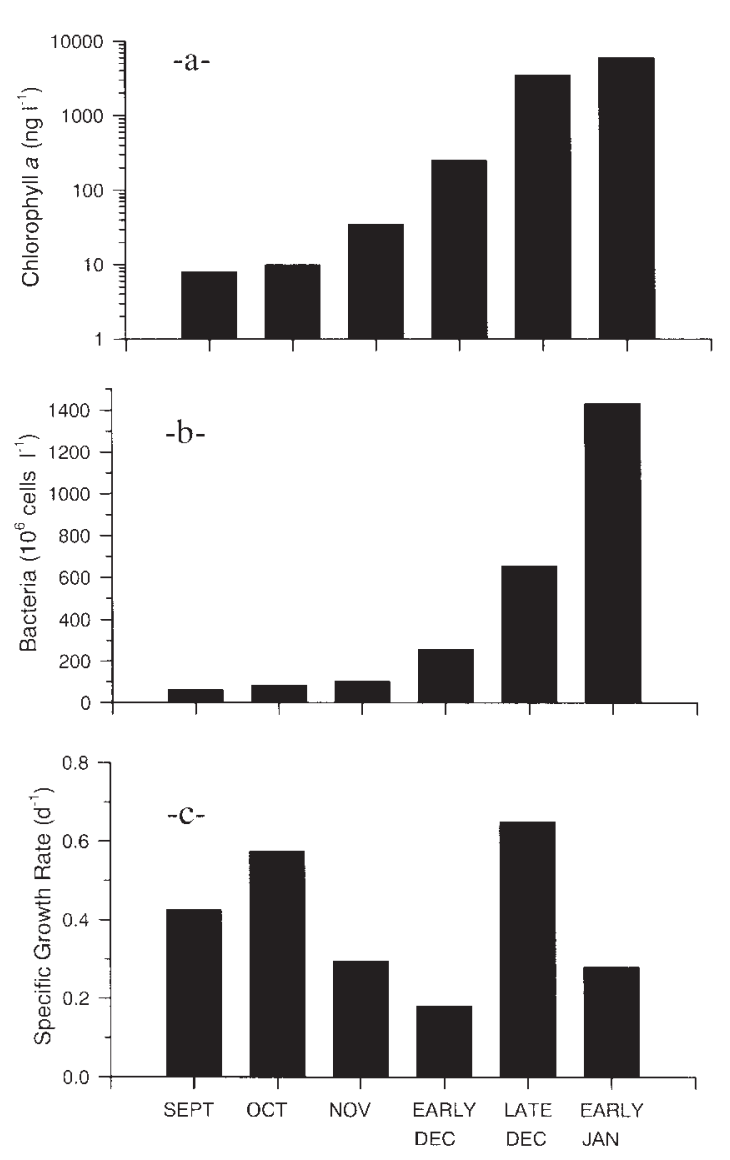

Fig. 2. Representative seasonal patterns of (a) chlorophyll $a$ $\left(\mathrm{ng} \mathrm{l}^{-1}\right)$, (b) bacterial abundance (cells $\mathrm{l}^{-1}$ ), and (c) SGR of bacteria from TdR incubations $\left(\mathrm{d}^{-1}\right)$ in McMurdo Sound, Antarctica. The month of December is divided into early and late periods since large and rapid changes in biomass and growth rates occurred during the second and third weeks. Data are available for only the first half of January. Each bar represents 3 to 5 sample periods

or indirectly (as sloppy feeding, metabolic by-products of micro- and meso-heterotrophs, etc.) into small particles. Bacterivorous and herbivorous flagellates and ciliates then transfer biomass from bacteria (and autotrophic picoplankton) to metazoan food webs. The dynamics and energetics of grazing and growth of these protists have been quantitatively studied in temperate and tropical oceans (Fenchel 1982, McManus \& Fuhrman 1988, Capriulo et al. 1991, Burkill et al. 1993, Peters 1994, Sherr \& Sherr 1994). However, the relative paucity of direct estimates of microzooplankton grazing in high latitude or cold oceans (Paranjape 1987, Moisan et al. 1991, Putt et al. 1991, Laurion et al. 1995) or for cultures of psychrophylic and psychrotrophic nanoflagellates (Choi \& Peters 1992) makes it difficult to directly assess the importance of microbial-mediated carbon fluxes in these regions. This results of the present study show that polar microzooplankton can 
consume nearly all the local bacterial production. There are, however, times of year when grazing mortality of bacteria is low to nil. During these periods, herbivory is the dominant trophic mode of the microzooplankton community.

\section{Importance of microbial foodweb in polar regions}

Two approaches can be taken to evaluate the importance of bacterial-based food webs in polar regions. One approach is to characterize the local distribution and growth rates of bacterioplankton, and this has been reviewed (Karl 1993, Rivkin et al. 1996). The result of a comprehensive statistical analysis of the relation between bacterial growth and seawater temperatures shows that growth rates of bacterioplankton from cold $\left(<4^{\circ} \mathrm{C}\right)$ and temperate $\left(>4^{\circ} \mathrm{C}\right)$ oceans were not significantly different (Rivkin et al. 1996). Yet in polar seas, bacterial abundances are relatively low and constant (Billen \& Becquevort 1991, Rivkin 1991, Thingstadt \& Martinussen 1991, Rivkin et al. 1996, Rivkin \& Anderson 2000), despite relatively high rates of growth. Steady-state abundance is the balance between growth and mortality; hence, the loss rates due to bacterivory (Anderson et al. 1990, Rivkin 1991) and viral lysis (Fuhrman \& Noble 1995, Maranger \& Bird 1995) must be similar to cell growth. Even a small imbalance may result in large oscillations in bacterial populations. For example, assuming an average specific growth rate of $0.4 \mathrm{~d}^{-1}$ (Rivkin et al. 1996), in the absence of grazing losses and viral lysis bacteria would increase from 1 to $55 \times \quad 10^{8} \mathrm{l}^{-1}$ in $10 \mathrm{~d}$. This is 5 - to 6 -fold higher than the maximum bacterioplankton abundance typically observed in polar systems. On the basis of this approach, we have calculated (Rivkin \& Anderson 2000) that 95 to $98 \%$ of bacterial production is removed by bacterivores or viruses.

A second approach is to estimate the potential for transfer of bacterial biomass to higher trophic levels. This can be done by characterizing the distribution and rates of grazing by heterotrophic microplankton. Although the distribution of microzooplankton in polar regions is reasonably well known (reviewed by Garrison et al. 1991, 1993), there are only a few direct measurements of bacterivory (Table 1). Based on the results of this study and a synthesis of published information on grazing (Table 1), it appears that, except immediately before and after the phytoplankton bloom periods, grazing mortality of bacteria was high and nearly all of the local bacterial production was ingested by microzooplankton.

Two general patterns in polar microbial dynamics emerge from this study: (1) During comparable sea- sons, in the Antarctic, bacterial abundance was 2- to 3 -fold higher whereas growth rates were 2- to 3-fold lower than in the Arctic. In contrast, the grazing mortality of bacterioplankton was similar in both systems. (2) In both the Arctic and Antarctic, seasonal variation in the abundance of bacteria was much less than that of phytoplankton. Bacterial abundances varied by approximately 5- to 25-fold over the season. This compares with a nearly 500- to 1000 -fold variation in chlorophyll a concentrations. What controls bacterioplankton abundances within this relatively narrow range? The principal factors regulating bacterial growth and abundances are temperature and nutrient supply (i.e., bottom-up control), and predation and viral mortality (i.e., top-down control), respectively. During late winter, early spring and the phytoplankton bloom, grazing mortality was a large (30 to >100\%) fraction of bacterial production (Table 1). During the periods immediately before and after the phytoplankton bloom, grazing rates were low to zero. When grazing was detectable, the rates of $k$ and $g$ were correlated ( $p<0.001$, Fig. 3) and described by the following functional (i.e., model 2) regression (Ricker 1973):

$g=0.955( \pm 0.1195) k-0.128( \pm 0.0508), \mathrm{r}^{2}=0.70, \mathrm{n}=21$

(values in parentheses are the standard errors of the estimates). The slope (0.955) of the above regression is not significantly different from $1(t=-0.5614, \mathrm{p}>0.50)$ while the intercept $(-0.128)$ is not significantly different from $0(t=-0.0863, \mathrm{p}>0.90)$. Since temperature

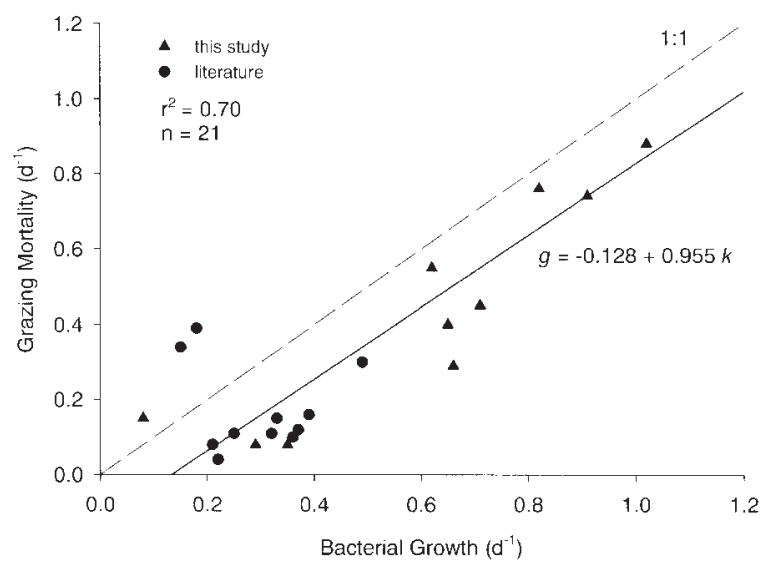

Fig. 3. Rate of grazing mortality $(g)$ as a function of bacterial growth $(k)$ for bacterioplankton from the Arctic and the Antarctic for all seasons, excluding the periods immediately before and after the phytoplankton bloom when grazing rates were low to nil. Data are from this study and from the literature (sources indicated in Table 1). The functional regression between $k$ and $g(g=0.955( \pm 0.1195) k-0.128( \pm 0.0508)$, values in parentheses are the standard errors of the estimates) is represented by the solid line. The dashed line represents the 1:1 relation 
does not vary in this environment, both growth rates and consequently grazing losses are likely controlled by nutrient (i.e., organic carbon and nitrogen) supply (Wiebe et al. 1992, Peters 1994, Rivkin et al. 1994, Rivkin \& Anderson 2000). During the winter, spring and phytoplankton bloom periods, grazing losses equaled bacterial growth and essentially all of the bacterial production was consumed by bacterivorous microzooplankton. Since grazing losses co-vary with growth rates, bacterivory appears to be the dominant factor controlling bacterial abundance in polar waters during most of the year.

\section{Regulation of grazing mortality}

An exception to the general model described above seems to occur during the pre- and post-bloom periods, when grazing mortality of bacteria is low to zero, despite measurable bacterial growth rates (Table 1). What accounts for this transient decrease in grazing mortality? Studies on protistan grazing show that grazer biomass, temperature, prey abundance and prey size are the primary variables controlling bacterivory (Peters 1994, Sherr \& Sherr 1994). In both the Arctic and Antarctic, temperature was constant throughout the season and bacterial abundances were near their seasonal maximum at the times when grazing was not detected. Furthermore, heterotrophic flagellate biomass is typically higher during and immediately after the phytoplankton bloom than earlier in the season (Bursa 1961, Garrison \& Buck 1989, Garrison \& Gowing 1993). We did not systematically measure bacterial cell size throughout the seasons; however, concurrent investigations carried out in McMurdo Sound showed a progressive 3-fold change in bacterial cell volume ( 0.4 to $1.1 \mathrm{\mu m}^{-3}$ ) between late November and mid-January. Maximum cell size coincided with the phytoplankton bloom (Putt et al. 1991, 1994). A similar pattern of change in cell size was observed over the season in Resolute Passage (Anderson unpubl. data). Heterotrophic flagellates preferentially ingest large and actively dividing bacteria and at higher rates than small, non-dividing cells (Andersson et al. 1986, Chrzanowski \& Simek 1990, Sherr et al. 1992, Peters 1994, Sherr \& Sherr 1994). This selection can significantly alter the size distribution of bacterioplankton populations (Ammerman et al. 1984, Andersson et al. 1986). However, it is unlikely that volume change alone would have resulted in the extreme change in grazing activity. The clearance and ingestion rates of Ochromonas danica and Bodo-like flagellates were 1.8- to 18.3-fold (median $=2.8, \mathrm{n}=8$ ) higher when bacterial prey size increased 3.3-fold from 0.36 to $1.19 \mu^{3}$ (Chrzanowski \& Simek 1990). Similar results were reported for natural microbial populations (Gonzalez et al. 1990). To assess the potential influence of changes in bacterial cell volume on grazing mortality requires making the 2 following assumptions: (1) bacterial cell volume during the pre- and post-bloom periods was at most 3.5 -fold smaller than during the bloom; and (2) there was a 1:1 relation between changes in bacterial cell volume and grazing rate (e.g., Fig. 3A in Gonzalez et al. 1990). If the alteration in cell volume were the dominant factor controlling changes in grazing characteristics of the microzooplankton at these times, grazing mortality should have been 0.22 to 0.25 $\mathrm{d}^{-1}$ (i.e., $0.76-0.88 \mathrm{~d}^{-1} \div 3.5$ ) in the Arctic and $0.17 \mathrm{~d}^{-1}$ (i.e., $0.58 \mathrm{~d}^{-1} \div 3.5$ ) in the Antarctic. These estimated rates are much higher than those observed during the periods in question for both polar regions (Table 1). While changes in cell size may have contributed to the observed decrease in bacterivory, they were not the only factor responsible. We propose that the observed patterns of grazing mortality of bacterioplankton were due to the combined interactions of changes in the chemical composition and nutritional characteristics of the bacterioplankton, as a result of nutrient limitation, with a concomitant reduction in cell size.

\section{Influence of growth and chemical composition}

Both the rates of growth and cell volume are significantly lower for nutrient-stressed than nutrient-replete bacterioplankton (Jaan et al. 1986, Gonzalez et al. 1993, Moyer \& Morita 1989, Nystrom et al. 1990). In environments where temperature is low and constant, such as in polar regions, nutrient availability regulates the patterns and rates of bacterial growth. Hence, when concentrations of DOC or DON are low, polar bacterioplankton would exhibit a hierarchical sequence of responses and progressively decrease size, alter chemical composition and, lastly, reduce cell division rate (Cooper 1991). Thus, bacterioplankton may show characteristics of nutrient limitation (e.g., altered cell size and chemical composition) before a significant reduction in growth rate. We assessed the nutritional status of bacterioplankton during the spring to summer transition in both McMurdo Sound (Rivkin et al. 1991, Rivkin \& Anderson 2000) and Resolute Bay (Rivkin et al. 1994, Rivkin \& Anderson 2000). These nutrient amendment studies showed that bacterial growth was enhanced by the amino acids during the pre-bloom and post-bloom periods, whereas at other times, nutrient additions did not significantly affect bacterial growth (Rivkin \& Anderson 2000). Data on ambient concentrations and seasonal patterns of DOC and DON in polar regions are scarce (Gordon \& Cranford 1985, Hubberten et al. 1995). However, during a study 
carried out concomitantly with ours, Welborn \& Manahan (1991) measured DOM in the sub-ice water column of McMurdo Sound. Dissolved amino acids and sugars increase from 50 and $200 \mathrm{nmol} \mathrm{l}^{-1}$, respectively, during the late winter and early spring to a maximum of 0.5 to 1.4 and $3.2 \mu \mathrm{mol} \mathrm{l^{-1 }}$, respectively, during the phytoplankton bloom in late December followed by a decrease in early January (Welborn \& Manahan 1991). Thus, the times when grazing mortality was low to zero coincided with times of year when bacteria were both small and appeared to be nutrient-stressed.

It is well known from studies on crustacean zooplankton that rapidly growing, nutrient-replete phytoplankton are ingested preferentially and at higher rates than nutrient-depleted phytoplankton (Cowles et al. 1988, Hessen 1992, Sterner \& Hessen 1994, and references cited therein). Few systematic studies on the influence of the nutritional quality of algal or bacterial prey on the ingestion characteristics of heterotrophic protists have been carried out. However, several lines of evidence suggest that both flagellates and ciliates have the ability to select prey based on chemical composition or nutritional status. For example, the rates of growth and ingestion, and the growth efficiency of Monas sp. at both limiting and saturating food concentrations were significantly influenced by the bacterial strain (Sherr et al. 1983): Goldman et al. (1985) showed that Paraphysomonas imperforata ingested fast-growing or phosphorus-replete bacteria more rapidly than slow-growing or phosphorus-depleted bacteria: during enclosure studies, the clearance rate of the microzooplankton community was positively correlated with bacterial production and production per cell (Hobbie \& Helfrich 1988): both flagellates and ciliates show a strong chemosensory response toward bacterial and algal prey. For example, ciliates both migrate toward specific algal taxa, even when the alga's C:N ratios are similar, and preferentially accumulate in chambers with exponentially growing algae and avoid chambers with slowly growing or stationary phase algae (Verity 1988). The heterotrophic flagellate Pseudobodo tremulans shows intense chemosensory attraction to nutrient-replete bacteria (Sibbald et al. 1987), with the highest index of chemotaxis observed for nutrientreplete bacteria, bacteria-free growth medium and $\mathrm{NH}_{4} \mathrm{Cl}$. Bacteria regenerate $\mathrm{NH}_{4}$ when concentrations of labile DON are high and sufficient to support rapid growth. This generally occurs when the C:N ratio of the bacteria $\left(\mathrm{C}: \mathrm{N}_{B}\right)$ is greater than the $\mathrm{C}: \mathrm{N}$ ratio of the substrate $\left(\mathrm{C}: \mathrm{N}_{\mathrm{S}}\right)$. In contrast, $\mathrm{NH}_{4}$ is assimilated from seawater when DON concentrations are low and $C: N_{B}$ < C: $\mathrm{N}_{\mathrm{S}}$ (Wheeler \& Kirchman 1986, Kirchman et al. 1989, 1990, Kirchman 1994). The above described observations strongly suggest that bacterivorous flagellates are able to locate nutrient-replete bacteria by using chemosensory cues to metabolic byproducts (e.g., $\mathrm{NH}_{4}$ ) of nutrient-sufficient growth.

\section{Seasonal patterns of nutrient dynamics in bacterivorous food webs}

Heterotrophic protozoa are responsible for a large proportion of nutrient regeneration in the sea (Azam et al. 1983). The rates, patterns and efficiency of nutrient regeneration are temporally and spatially variable and are strongly influenced by the difference between the nutrients required for the synthesis of protozoan biomass and the nutrient content of the prey (Goldman et al. 1987, Caron 1991, Anderson 1992). For example, when the $C: N$ ratio of the protozoa $\left(C: N_{\text {pro }}\right)$ is greater than the $C: N$ of its prey $\left(C: N_{\text {pre }}\right)$, the rate of nitrogen excretion by the protist is high. In contrast, when $\mathrm{C}: \mathrm{N}_{\mathrm{pro}}<\mathrm{C}: \mathrm{N}_{\text {pree }}$ the prey are depleted in nitrogen relative to carbon and the rate of nitrogen excretion by the predator is low. The range in $\mathrm{C}: \mathrm{N}_{\text {pro }}$ is relatively small (e.g., 5.1 to 8.9 , mean $=6.8$, coefficient of variation $[C V]=12 \%$; Anderson 1992, Goldman et al. 1987). In contrast, the range in $\mathrm{C}: \mathrm{N}_{\text {pre }}$ is taxon dependent; for bacteria, the $\mathrm{C}: \mathrm{N}$ ratio is considerably lower and less variable (i.e., 2.9 to 8.7 , mean $=5.2, \mathrm{CV}=30 \%$; Caron 1991, Anderson 1992) than that of phytoplankton (i.e., 5 to 25 , mean $=12.4, \mathrm{CV}=53 \%$; Caron 1991). On the basis of the above theoretical consideration, more nitrogen would be remineralized by bacterivorous than herbivorous protists. Within a trophic mode (bacterivory or herbivory), the rates of regeneration would be greater for nutrient-replete than nutrient-depleted prey. Since the stoichiometric requirement for nutrients by protozoa is narrow relative to that of their prey, the nutrient in shortest supply would be conserved (Goldman et al. 1987). Hence, when the growth of the prey is limited by the availability of a nutrient, progressively smaller quantities of the limiting nutrient would be regenerated.

On the basis of the above described interactions between protistan grazers and their prey, and the associated rates and efficiencies of nutrient regeneration, we propose the following model (Table 2) to explain the temporal pattern of protozoan grazing in high latitude, ice-covered oceans:

(1) During the winter and early spring, bacterial biomass and growth rates are low. The microbial loop (sensu strictum, bacteria and bacterivorous microflagelates in a quasi-closed loop, Legendre \& Rassoulzadegan 1995) dominates, protozooplankton are bacterivorous and grazing mortality is high. For the reasons given above (i.e., C: $\mathrm{N}_{\text {pro }}>\mathrm{C}: \mathrm{N}_{\text {pre }}$ ), regeneration rates are relatively high.

(2) During the transition from early spring to late spring and early summer (e.g., pre-phytoplankton bloom period), bacterial biomass and growth rates are 
Table 2. Matrix of interactions showing changes that occur within the microbial community over the season in polar waters. See text for a complete description of the interactions.

\begin{tabular}{|c|c|c|c|c|}
\hline & Late winter & Spring & Summer & Late summer \\
\hline Phytoplankton status & Non-bloom & Pre-bloom & Bloom & Post-bloom \\
\hline Algal biomass & Very low & Low & High & Intermediate \\
\hline Bacterial biomass & Low & Low & Intermediate & High \\
\hline Bacterial growth & Intermediate & Low & High & Intermediate \\
\hline Bacterial grazing mortality & High & Low & High & Low \\
\hline$C: N_{\text {phy }}$ & Low & Low & Low & High \\
\hline$C: N_{\text {pro }} C: N_{\text {pre }}$ & $C: N_{\text {pro }}>C: N_{\text {pre }}$ & $C: \mathrm{N}_{\text {pro }} \leq \mathrm{C}: \mathrm{N}_{\mathrm{pre}}$ & C: $\mathrm{N}_{\text {pro }}<\mathrm{C}: \mathrm{N}_{\text {pre }}$ & $\mathrm{C}: \mathrm{N}_{\text {pro }}<<\mathrm{C}: \mathrm{N}_{\text {pre }}$ \\
\hline$C: \mathrm{N}_{\mathrm{B}} \mathrm{C}: \mathrm{N}_{\mathrm{S}}$ & $C: \mathrm{N}_{\mathrm{B}}>\mathrm{C}: \mathrm{N}_{\mathrm{S}}$ & $C: N_{B}<C: N_{S}$ & $C: N_{B} \leq C: N_{S}$ & $C: N_{B}<<C: N_{S}$ \\
\hline Nitrogen regeneration & High & Low & Intermediate & Low \\
\hline DOC release by phytoplankton & Low & Low & High & High \\
\hline Dominant trophic mode & Bacterivory & Herbivory & Bacterivory/herbivory & Herbivory \\
\hline Microbial trophic pathway ${ }^{\mathrm{a}}$ & Microbial loop & Microbial food web & Multivorous food web & Multivorous food web \\
\hline \multicolumn{5}{|c|}{$\begin{array}{l}\text { *Sensu Legendre \& Rassoulzadegan (1995) } \\
C: N_{\text {phy }}=\text { carbon to nitrogen ratio of phytoplankton; } C: N_{\text {pro }} C: N_{\text {pre }}=\text { carbon to nitrogen ratios of protozoa versus prey; } \\
\text { C: } N_{B} C: N_{S}=\text { carbon to nitrogen ratios of bacteria to substrate }\end{array}$} \\
\hline
\end{tabular}

low. The increase in submarine irradiance promotes the growth of phytoplankton. With the increased availability of phytoplankton prey, the microbial food web (a more open system including autotophic pico- and nanoplankton; Legendre \& Rassoulzadagan 1995) dominates and protozooplankton ingest variable proportions of bacteria and phytoplankton. Since prey carbon is now enriched relative to nitrogen, the rate of nitrogen regeneration declines (e.g., C: $\mathrm{N}_{\text {pro }} \leq \mathrm{C}: \mathrm{N}_{\text {pre }}$ ). The combined effects of the reduced rate of nitrogen remineralization by protozoan grazers and increased concentrations of DOC released by the more abundant phytoplankton (Williams 1990, Wood \& Van Valen 1990) lead to $C: N_{S}>C: N_{B}$. Consequently, we propose that the bacterioplankton may become nitrogen stressed as the bloom approaches, and the rate of grazing mortality on the nutrient-limited bacteria decreases.

(3) During the bloom, phytoplankton are nutrient replete. Although the regeneration efficiency of nitrogen is relatively low (e.g., C: $\mathrm{N}_{\text {pro }}<\mathrm{C}: \mathrm{N}_{\text {pre }}$ ), the combined effects of high grazing rates by herbivorous protozooplankton and mesozooplankton, and the relatively low $\mathrm{C}: \mathrm{N}_{\text {pre }}$ of the nutrient replete phytoplankton (e.g., $C: N=6$ to 7 , compared with $C: N \geq 15$ for nitrogen-limited phytoplankton) result in sufficient nitrogen regeneration to support rapid growth of nutrientreplete bacterioplankton. Consequently, the grazing mortality of the bacterioplankton increases during the bloom.

(4) The depletion of inorganic nutrients leads to the termination of the phytoplankton bloom and an increase in the C:N ratio of the phytoplankton. Because
$\mathrm{C}: \mathrm{N}_{\text {pro }}<\mathrm{C}: \mathrm{N}_{\text {pre, }}$ the rate of nitrogen regeneration by herbivorous protozoa is low. This leads to an increase in the C:N ratio of DOM and potential nutrient limitation for the bacteria. Thus, during the post-bloom period, bacteria are nutrient stressed and the rates of growth and grazing mortality are again low.

\section{Conclusion}

It is clear that the microzooplankton community in polar regions is highly active and can potentially consume most of the local bacterial production. By selectively ingesting the larger and actively dividing bacteria, protozoan grazers preferentially consume bacterial production rather than randomly ingesting the standing stock (Krambeck \& Krambeck 1984, Gonzalez et al. 1990). Protozoan communities appear to alternate between bacterivorous and herbivorous nutritional modes as prey fields change in response the seasonal progression in submarine irradiance and dissolved nutrients. Moreover, there appears to be a feedback mechanism between phagotrophic protists and their prey that is mediated through the control on substrate availability. The timing and magnitude of the phytoplankton bloom and the duration of the post-bloom period exert a significant influence on the flux of bacterioplankton carbon through protozooplankton and ultimately the coupling of the microbial and metazoan food webs.

Acknowledgements. Research in the Arctic was supported by 
grants from the National Science Foundation (NSF) of the United States to MRA (DPP-9114293) and RBR (DPP-9113963) and by grants from the Natural Science and Engineering Research Council of Canada to RBR. Research in the Antarctic was supported by grants from the NSF to RBR (DPP8820132). We thank the Antarctic staff of the NSF, Naval Support Force Antarctica, ITT and ASA Antarctic Service for logistic and sampling support in McMurdo Sound. We especially thank Dr Buster Welch, Department of Fisheries and Oceans, and Polar Continental Shelf Project for logistic and sampling support in the Arctic. This research would not have been possible without our excellent field teams in both the Antarctic (D. Gustafson and V. Pearce) and Arctic (C. LeDrew, P. Matthews, J. Scott and O. Werpin). We also thank D. Scruton and Drs B. Mostajir, P. Pepin, S. Grossman and L. Pomeroy, and 2 anonymous reviewers for helpful comments on the manuscript.

\section{LITERATURE CITED}

Ammerman JW, Fuhrman JA, Hagström ^, Azam F (1984) Bacterioplankton growth in seawater: growth kinetics and cellular characteristics in seawater cultures. Mar Ecol Prog Ser 18:31-39

Andersen OK, Goldman JC, Caron DA, Dennett MR (1986) Nutrient cycling in a microflagellate food chain: III. Phosphorus dynamics. Mar Ecol Prog Ser 31:47-55

Andersen P (1988) The quantitative importance of the 'Microbial Loop' in the marine pelagic: a case study from the north Bering/Chukchi seas. Arch Hydrobiol Beih Ergeb Limnol 31:243-251

Anderson MR, Rivkin RB, Gustafson DE (1990) The fate of bacterial production in McMurdo Sound in the austral spring. Antarct J US 25:193-194

Anderson TR (1992) Modeling the influence of food C:N ratio, and respiration on growth and nitrogen excretion in marine zooplankton and bacteria. J Plankton Res 14: 1645-1671

Andersson A, Larsson U, Hagström ^̊ (1986) Size-selective grazing by a microflagellate on pelagic bacteria. Mar Ecol Prog Ser 33:51-57

Azam F (1998) Microbial control of oceanic carbon flux: the plot thickens. Science 280:694-696

Azam F, Fenchel T, Field JG, Gray JS, Meyer-Reil LA, Thingstadt F (1983) The ecological role of water-column microbes in the sea. Mar Ecol Prog Ser 10:257-263

Azam F, Smith DC, Hollibaugh JT (1991) The role of the microbial loop in Antarctic pelagic ecosystems. Polar Res 10:239-243

Azam F, Smith DC, Steward GF, Hagström Å (1994) Bacteriaorganic matter coupling and its significance for oceanic carbon cycling. Microb Ecol 28:167-179

Becquevort S (1997) Nanoprotozooplankton in the Atlantic sector of the Southern Ocean during early spring: biomass and feeding activities. Deep-Sea Res II 44:355-373

Berhenfeld MJ, Falkowski PG (1997) Photosynthetic rates derived from satellite-based chlorophyll concentrations. Limnol Oceanogr 42:1-20

Bernard C, Rassoulzadegan F (1990) Bacteria or microflagellates as a major food source for marine ciliates: possible implications for the microzooplankton. Mar Ecol Prog Ser 64:147-155

Billen B, Becquevort S (1991) Phytoplankton-bacteria relationship in the Antarctic marine ecosystem. Polar Res 10: 245-253

Bird DF, Karl DM (1999) Uncoupling of bacteria and phyto- plankton during the austral spring bloom in Gerlache Strait, Antarctic Peninsula. Aquat Microb Ecol 19:13-27

Bjørnsen PK, Kuparinen J (1991) Determination of bacterioplankton biomass, net production and growth efficiency in the Southern Ocean. Mar Ecol Prog Ser 71:185-194

Buck KR, Garrison DL (1983) Protists from the ice edge region of the Weddell Sea. Deep-Sea Res 30:1261-1277

Burkill PH, Leakey RJG, Owens NJP, Mantoura RFC (1993) Synechococcus and its importance to the microbial food web of the northwestern Indian Ocean. Deep-Sea Res 40: $773-782$

Bursa AS (1961) The annual cycle at Igloolik in the Canadian Arctic. II. The phytoplankton. J Fish Res Board Can 18: 563-615

Capriulo GM, Sherr EB, Sherr BF (1991) Trophic behaviour and related community feeding activities of heterotrophic marine protists. In: Reid PC, Turley CM, Burkill PH (eds) Protozoa and their role in marine processes. NATO ASI Series G25:219-265

Carlson CA, Ducklow HW, Hansell DS, Smith WO (1998) Organic carbon partitioning during spring phytoplankton blooms in the Ross Sea Polynya and the Sargasso Sea. Limnol Oceanogr 43:375-386

Caron DA (1991) Evolving role of protozoa in aquatic nutrient cycles. In: Reid PC, Turley CM, Burkill PH (eds) Protozoa and their role in marine processes. NATO ASI Series G25: $387-416$

Caron DA (1994) Inorganic nutrients, bacteria and the microbial loop. Microb Ecol 28:295-298

Caron DA, Goldman JC, Andersen OK, Dennett MR (1985) Nutrient cycling in a microflagellate food chain: II. Population dynamics and carbon cycling. Mar Ecol Prog Ser 24: $243-254$

Cho BC, Azam F (1990) Biogeochemical significance of bacterial biomass in the ocean's euphotic zone. Mar Ecol Prog Ser 63:253-259

Choi JW, Peters F (1992) Effects of temperature on two psychrophylic ecotypes of a heterotrophic nanoflagellate, Paraphysomonas imperforata. Appl Environ Microbiol 58: 593-599

Chrzanowski TH, Šimek K (1990) Prey-size selection by freshwater flagellated protozoa. Limnol Oceanogr 35: 1429-1436

Cole JJ, Findlay S, Pace ML (1988) Bacterial production in fresh and saltwater ecosystems: a cross-system overview. Mar Ecol Prog Ser 43:1-10

Cooper S (1991) Bacterial growth and division: biochemistry and regulation of prokaryotic and eukaryotic division cycles. Academic Press, San Diego

Cowles TJ, Olson RJ, Chisholm SW(1988) Food selection by copepods: discrimination on the basis of food quality. Mar Biol 100:41-49

Ducklow H (1991) The passage of carbon through microbial foodwebs: results from flow network models. Mar Microb Food Webs 5:129-144

Ducklow HW (1999) The bacterial component of the ocean euphotic zone. FEMS Microbiol Ecol 30:1-10

Ducklow H (2000) Bacterial production and biomass in the ocean. In: Kirchman DL (ed) Microbial ecology of the sea, Vol 4. Wiley Liss, Inc, New York, p 85-120

Evans GT, Paranjape MA (1992) Precision of estimates of phytoplankton growth and microzooplankton grazing when the functional response of grazers may be nonlinear. Mar Ecol Prog Ser 80:285-290

Fenchel T (1982) Ecology of some heterotrophic microflagellates. IV. Quantitative occurrence and importance as bacterial consumers. Mar Ecol Prog Ser 9:5-42 
Findlay S, Pace ML, Lints D, Cole JJ, Caraco NF, Peierls B (1991) Weak coupling of bacterial and algal production in a heterotrophic ecosystem: The Hudson River estuary. Limnol Oceanogr 36:268-278

Fortier L, Le Fevre J, Legendre L (1994) Export of biogenic carbon to fish and to the deep ocean: the role of large plankton microphages. J Plankton Res 16:809-839

Fuhrman JA, Noble RT (1995) Viruses and protists cause similar bacterial mortality in coastal seawater. Limnol Oceanogr 40:1236-1242

Garrison DL, Buck KR (1989) Protozooplankton in the Weddell Sea, Antarctica: abundance and distribution in the ice-edge zone. Polar Biol 9:341-351

Garrison DL, Gowing MM (1993) Protozooplankton. In: Freidman EI (ed) Antarctic microbiology. Wiley-Liss, New York, p 123-165

Garrison DL, Buck KR, Gowing MM (1991) Plankton assemblages in the ice edge zone of the Weddell Sea during the austral winter. J Mar Syst 2:123-130

Garrison DL, Buck KR, Gowing MM (1993) Winter plankton assemblage in the ice edge zone of the Weddell and Scotia Seas: composition, biomass and spatial distributions. Deep-Sea Res 40:311-338

Goldman JC, Caron DA, Andersen OK, Dennett MR (1985) Nutrient cycling in a microflagellate food chain. I. Nitrogen dynamics. Mar Ecol Prog Ser 24:231-242

Goldman JG, Caron DA, Dennett MR (1987) Nutrient cycling in a microflagellate food chain. IV. Phytoplanktonmicroflagellate interactions. Mar Ecol Prog Ser 38:75-87

Gonzalez JM, Sherr EB, Sherr BF (1990) Size-selective grazing on bacteria by natural assemblages of estuarine flagellates and ciliates. Appl Environ Microbiol 56:583-589

Gonzalez JM, Sherr EB, Sherr BF (1993) Differential feeding by marine flagellates on growing versus starving, and on motile versus nonmotile, bacterial prey. Mar Ecol Prog Ser 102:257-267

Gordon DC Jr, Cranford PJ (1985) Detailed distribution of dissolved and particulate organic matter in the Arctic Ocean and comparison with other oceanic regions. Deep-Sea Res 32:1221-1232

Hessen DO (1992) Nutrient element limitation of zooplankton production. Am Nat 140:799-814

Hobbie JE, Helfrich JVK III (1988) The effect of grazing by microprotozoans on production of bacteria. Arch Hydrobiol Beih Ergeb Limnol 31:281-288

Hobbie JE, Daley RJ, Jasper S (1977) Use of nuclepore filters for counting bacteria by fluorescence microscopy Appl Environ Microbiol 33:1225-1227

Hoch MP, Kirchman DL (1993) Seasonal and inter-annual variability in bacterial production and biomass in a temperate estuary. Mar Ecol Prog Ser 98:283-295

Hubberten U, Lara RJ, Kattner G (1995) Refractory organic compounds in polar waters: relationship between humic substances and amino acids in the Arctic and Antarctic. J Mar Res 53:137-149

Jaan AJ, Dahllof B, Kjelleberg S (1986) Changes in protein composition of three bacterial isolates from marine waters during short periods of energy and nutrient deprivation. Appl Environ Microbiol 52:1419-1421

Karl DM (1993) Microbial processes in the Southern Oceans. In: Freidman EI (ed) Antarctic microbiology. Wiley-Liss, New York, p 1-63

Kelly CA, Pakulski JD, Sandvick SLH, Coffin RB, Downer RC, Aas P, Lyons MM, Jeffrey WH (1999) Phytoplanktonic and bacterial carbon pools and productivities in the Gerlache Strait, Antarctica, during early austral spring. Microb Ecol 38:296-305
Kirchman DL (1994) The uptake of inorganic nutrients by heterotrophic bacteria. Microb Ecol 28:255-271

Kirchman DL, Hoch MP (1988) Bacterial production in the Delaware Bay estuary estimated from thymidine and leucine incorporation rates. Mar Ecol Prog Ser 45:169-178

Kirchman DL, Ducklow HW, Mitchell R (1982) Estimates of bacterial growth from changes in uptake rates and biomass. Appl Environ Microbiol 44:1296-1307

Kirchman DL, Soto Y, Van Wambeck F, Bianchi M (1989) Bacterial production in the Rhone River plume: Effect of mixing on relationships among microbial assemblages. Mar Ecol Prog Ser 53:267-275

Kirchman DL, Keil RG, Wheeler PA (1990) Carbon limitation of ammonium uptake by heterotrophic bacteria in the Subarctic Pacific. Limnol Oceanogr 35:1258-1266

Krambeck C, Krambeck HJ (1984) Morphometric analysis of cell-cycle responses in bacterioplankton. Arch Hydrobiol Beih Ergeb Limnol 19:111-118

Kuparinen J, Bjornsen PK (1992) Bottom-up and top-down controls of the microbial food web in the Southern Ocean: experiments with manipulated microcosms. Polar Biol 12: 189-195

Landry MR (1993) Estimating rates of growth and grazing mortality of photoautotrophic plankton by dilution. In: Kemp PF, Sherr BF, Sherr EB, Cole JJ (eds) Handbook of methods in aquatic microbial ecology. Lewis Publishers, Boca Raton, p 715-722

Landry MR, Hassett RP (1982) Estimating grazing impact of marine micro-zooplankton. Mar Biol 67:283-288

Laurion I, Demers S, Vezina AF (1995) The microbial food web associated with the ice algal assemblage: biomass and bacterivory of nanoflagellate protozoans in Resolute Passage (High Canadian Arctic). Mar Ecol Prog Ser 120: $77-87$

Leakey RJG, Archer SD, Grey J (1996) Microbial dynamics in coastal waters of East Antarctica: bacterial production and nanoflagellate bacteria. Mar Ecol Prog Ser 142:3-17

Legendre L, Le Fevre J (1995) Microbial food webs and the export of biogenic carbon in the oceans. Aquat Microb Ecol 9:69-77

Legendre L, Rassoulzadegan F (1995) Plankton and nutrient dynamics in marine waters. Ophelia 41:153-172

Longhurst A, Sathyendranath S, Platt T, Caverhill C (1995) An estimate of global primary production in the ocean from satellite radiometer data. J Plankton Res 17:1245-1271

Maranger R, Bird DF (1995) Viral abundance in aquatic systems: a comparison between marine and fresh waters. Mar Ecol Prog Ser 121:217-226

Maranger R, Bird DF, Juniper SK (1994) Viral and bacterial dynamics in Arctic sea ice during the spring algal bloom near Resolute, N.W.T., Canada. Mar Ecol Prog Ser 111: 121-127

Marchant HJ, Scott FJ (1993) Uptake of sub-micrometre particles and dissolved organic material by Antarctic choanoflagellates. Mar Ecol Prog Ser 92:59-64

McManus GB, Fuhrman JA (1988) Clearance of bacteriasized particles by natural populations of nanoplankton in the Chesapeake Bay outflow plume. Mar Ecol Prog Ser 42: 199-206

Moisan T, Putt M, Stoecker D (1991) Bacterivory in McMurdo Sound: 2. Information from size-fractionation experiments. Antarct J US 26:141-142

Moyer CL, Morita RY (1989) Effect of growth rate and starving-survival on the viability and stability of psychrophylic marine bacteria. Appl Environ Microbiol 55:1122-1127

Nöthig EM, von Bodungen B, Sui Q (1991) Phyto- and protozooplankton biomass during austral summer in surface 
waters of the Weddell Sea and vicinity. Polar Biol 11: 293-304

Nystrom T, Albertson NH, Flardh K, Kjellberg S (1990) Physiological and molecular adaptation to starvation and recovery from starvation by the marine Vibrio sp. S14. FEMS Microb Ecol 74:129-140

Paranjape MA (1987) Grazing by microzooplankton in the eastern Canadian Arctic in summer 1983. Mar Ecol Prog Ser 40:239-246

Paranjape MA (1988) Microzooplankton in Lancaster Sound (Eastern Canadian Arctic) in summer: biomass and distribution. Deep-Sea Res 35:1547-1563

Peters F (1994) Prediction of protistan grazing rates. Limnol Oceanogr 39:195-206

Pomeroy LR, Weibe WJ (1993) Energy sources for microbial foodwebs. Mar Microb Foodwebs 7:101-118

Putt M, Stoecker D, Alstatt J (1991) Bacterivory in McMurdo Sound: 1. Grazing by heterotrophic nanoflagellates. Antarct J US 26:139-140

Putt M, Miceli G, Stoecker D (1994) Association of bacteria with Phaeocystis sp. in McMurdo Sound, Antarctica. Mar Ecol Prog Ser 105:179-189

Rassoulzadegan F (1982) Dependence of grazing rate, gross growth efficiency and food size range on temperature in a pelagic oligotrichous ciliate Lohmanniella spiralis Leeg., fed on naturally occurring particulate matter. Ann Inst Oceanogr Paris 58:177-184

Rich J, Gosselin M, Sherr E, Sherr B, Kirchman DL (1997) High bacterial production, uptake and concentrations of dissolved organic matter in the Central Arctic Ocean. Deep-Sea Res II 44:1645-1663

Ricker WE (1973) Linear regression in fisheries research. J Fish Res Board Can 30:409-434

Riemann B, Bjoernsen PK, Newell S, Fallon R (1987) Calculation of cell production of coastal marine bacteria based on measured incorporation of $\left({ }^{3} \mathrm{H}\right)$ thymidine. Limnol Oceanogr 32:471-476

Rivkin RB (1991) Seasonal patterns of planktonic production in McMurdo Sound, Antarctica. Am Zool 31:5-16

Rivkin RB, Anderson MR (2000) Microbial dynamics in polar oceans: a bipolar comparison. In: Brylinsky M, Bell C, Johnson-Green P (eds) Microbial biosystems: new frontiers. Proc 8th Int Symp Microb Ecol. Atlantic Canada Society for Microbial Ecology, Halifax, Nova Scotia, p 307-316

Rivkin RB, Legendre L (2001) Biogenic carbon cycling in the upper ocean: effects of microbial respiration. Science 291: $2398-2400$

Rivkin RB, Anderson MR, Gustafson DE Jr (1991) Dynamics of bacterioplankton growth in McMurdo Sound, Antarctica: evidence for substrate sufficient growth. Ant J US 26:145-146

Rivkin RB, Matthews, PLJ, LeDrew C (1994) Microbial processes in High Arctic marine communities. 2. Bacterioplankton. EOS 75:73

Rivkin RB, Anderson MR, Lajzerowicz CJ (1996) Microbial processes in cold oceans. 1. Relationships between temperature and bacterial growth rate. Aquat Microb Ecol 10: 243-254

Rivkin RB, Putland JN, Anderson, MR, Deibel D (1999) Microzooplankton bacterivory and herbivory in the Subarctic

Editorial responsibility: Fereidoun Rassoulzadegan, Villefrance-sur-Mer, France
Pacific. Deep-Sea Res II 46:2579-2618

Sherr BF, Sherr EB (1991) Proportional distribution of total numbers, biovolume, and bacterivory among size classes of 2-20 $\mu \mathrm{m}$ nonpigmented marine flagellates. Mar Microb Food Webs 5:227-237

Sherr BF, Sherr EB (1994) Bacterivory and herbivory: key roles of phagotrophic protists in pelagic food webs. Microb Ecol 28:223-236

Sherr BF, Sherr EB, Berman T (1983) Grazing, growth, and ammonium excretion rates of a heterotrophic microflagellate fed with four species of bacteria. Appl Environ Microbiol 45:1196-1201

Sherr BF, Sherr EB, McDaniel J (1992) Effect of protistan grazing on the frequency of dividing cells in bacterioplankton assemblages. Appl Environ Microbiol 58: 2381-2385

Sherr EB, Sherr BF, Fessenden L (1997) Heterotrophic protists in the Central Arctic Ocean. Deep-Sea Res II 44: 1665-1682

Sibbald MJ, Albright LJ, Sibbald PR (1987) Chemosensory responses of a heterotrophic microflagellate to bacteria and several nitrogen compounds. Mar Ecol Prog Ser 36: 201-204

Sterner RW, Hessen DO (1994) Algal nutrient limitation and the nutrition of aquatic herbivores. Annu Rev Ecol Syst 25: $1-29$

Taniguchi A (1984) Microzooplankton biomass in the arctic and subarctic Pacific Ocean in the summer. Mem Natl Inst Polar Res (Spec issue) 32:63-76

Thingstadt TF, Martinussen I (1991) Are bacteria active in the cold pelagic ecosystem of the Barents Sea? Polar Res 10: 255-266

Thingstadt TF, Rassoulzadegan F (1995) Nutrient limitations, microbial food webs, and 'biological C-pumps': suggested interactions in a P-limited Mediterranean. Mar Ecol Prog Ser 117:299-306

Tranvik L (1992) Effects of colloidal matter on the growth of bacteria and protists in lake water. Limnol Oceanogr 39:1276-1285

Verity PG (1985) Grazing, respiration, excretion and growth rates of tintinnids. Limnol Oceanogr 30:1268-1282

Verity PG (1988) Chemosensory behavior in marine planktonic ciliates. Bull Mar Sci 43:772-782

Weibe WJ, Sheldon WM, Pomeroy LR (1992) Bacterial growth in the cold: evidence for enhanced substrate requirement. Appl Environ Microbiol. 58:359-364

Welborn JR, Manahan DT (1991) Seasonal changes in concentrations of amino acids and sugars in seawaters of McMurdo Sound, Antarctica: uptake of amino acids by asteroid larvae. Antarct J US 26:160-162

Wheeler PA, Kirchman DL (1986) Utilization of inorganic and organic nitrogen by bacteria in marine systems. Limnol Oceanogr 31:998-1009

White PA, Kalff J, Rasmussen JB, Gasol JM (1991) The effect of temperature and algal biomass on bacterial production and specific growth rate in freshwater and marine habitats. Microb Ecol 21:99-118

Williams PJL (1990) The importance of losses during microbial growth. Commentary on the physiology, measurement and ecology of the release of dissolved organic material. Mar Microb Food Webs 4:175-206

Submitted: May 24, 2000; Accepted: May 31, 2001

Proofs received from author(s): August 29, 2001 